\title{
Kernos
}

Revue internationale et pluridisciplinaire de religion grecque antique

$25 \mid 2012$

Varia

\section{Seized by the Nymph?}

Onesagoras the 'dekatephoros' in the Nymphaeum at Kafizin in Cyprus

\section{Theodora Suk Fong Jim}

\section{Q OpenEdition \\ 1 Journals}

Édition électronique

URL : http://journals.openedition.org/kernos/2101

DOI : 10.4000/kernos. 2101

ISSN : 2034-7871

Éditeur

Centre international d'étude de la religion grecque antique

\section{Édition imprimée}

Date de publication : 26 octobre 2012

Pagination : 9-26

ISSN : 0776-3824

\section{Référence électronique}

Theodora Suk Fong Jim, « Seized by the Nymph? », Kernos [En ligne], 25 | 2012, mis en ligne le 20 novembre 2014, consulté le 15 octobre 2019. URL : http://journals.openedition.org/kernos/2101 DOI : 10.4000/kernos.2101 


\title{
Seized by the Nymph? \\ Onesagoras the 'dekatephoros' in the Nymphaeum at Kafizin in Cyprus
}

\begin{abstract}
While dedicatory practices have been a subject of frequent studies by historians of Greek religion, existing scholarship has paid little or no attention to an important dossier of inscriptions from Cyprus: on the conical hill of Kafizin is a cave-sanctuary where some 310 inscribed items of pottery have been excavated, the vast majority of which were inscribed with the name Onesagoras, son of Philounios, and were dedicated to a Nymph between 225 and 218 B.C. Onesagoras displayed such an intensity in his worship of the Nymph that he may be thought of as a nympholept or as being possessed by the Nymph. The dossier makes available important material for the study of religious practices at the subpolis level. This article aims to bring this material to the attention of students and scholars of Greek religion and to raise questions concerning dedicatory practices.
\end{abstract}

Résumé : Alors que les pratiques dédicatoires ont été régulièrement étudiées par les historiens de la religion grecque, un important dossier chypriote a jusqu'ici été quasiment négligé. Il s'agit d'un sanctuaire rupestre situé sur la colline de Kafizin, où quelque 310 fragments de céramique inscrits ont été mis au jour, dont la grande majorité porte le nom d'Onesagoras, fils de Philounios, et est dédiée à une Nymphe, entre 225 et 218 avant notre ère. Onesagoras a manifesté une telle intensité dans le culte de la Nymphe qu'il peut être considéré comme un nympholepte ou "possédé par une Nymphe ». Le dossier comprend un matériel important pour l'étude des pratiques religieuses à un niveau intermédiaire dans la polis. Cet article entend porter ce matériel à l'attention de ceux qui étudient la religion grecque, en soulevant les questions qu'il pose en matière de pratiques dédicatoires.

One of the most interesting dossiers of epigraphic evidence for the study of dedicatory practices has come down to us from the little known cave-sanctuary at Kafizin in Cyprus. Situated some four miles to the south-east of Nicosia, and some seven miles north of Dhali (the site of the ancient city Idalium), ${ }^{1}$ the hill of Kafizin has a grotto dedicated to a Nymph near its summit. Excavations in 1939 and 1949, followed by supplementary excavations between 1950 and 1955, have brought to light a large number of pottery fragments. The finds

${ }^{*}$ I am most grateful to Professor Robert Parker for commenting on earlier versions of this article. I thank also the anonymous referee of Kernos for helpful suggestions, and Matthew Gibbs for discussing with me aspects of Hellenistic associations.

${ }^{1}$ On Idalium, see HANSEN and Nielsen (2004), p. 1225, no. 1013. 
were published by Mitford in The Nymphaeum of Kafizin (1980), ${ }^{2}$ a collection of 309 items involving a diversity of ceramic vessels and terracotta utensils with incised inscriptions in Greek or Cypriotic syllabic script or in both, dated between 225 and 218 B.C. ${ }^{3}$ The finds are exciting for various reasons. First, they show that the syllabic script and the Cypro-Arcadian dialect still flourished in Cyprus in the last quarter of the third century B.C., ${ }^{4}$ later than traditionally believed. Second, the inscriptions contain many rare or otherwise unknown words with obscure meanings. Third, they are revealing about the rural economy of early Hellenistic Cyprus. Finally, they testify to the devotion of an individual (or possibly a group) and his close relation with a goddess, presenting us with valuable material for the study of dedicatory practices. However, this dossier has attracted little or no attention among historians of Greek religion in the last three decades. ${ }^{5}$ The aim of this article is to remedy that neglect, and to pose questions concerning dedicatory practices.

It is striking that 269 out of the 310 inscribed items of pottery appear to have been dedicated by an individual Onesagoras, son of Philounios, ${ }^{6}$ mostly in his own name, but in a few instances jointly with other dedicant(s). ${ }^{7}$ The vessels were inscribed with his name, and were addressed almost exclusively to one Nymph. ${ }^{8}$ These dedications were brought to the goddess over a period of eight years (225-218 B.C.); 9 and what is preserved represents probably only a fraction of what was actually dedicated. The phenomenon is so remarkable that at first sight it may appear tantalizingly inexplicable to historians. In fact Onesagoras was not alone in worshipping the Nymph with such intensity. Towards the end of the fifth century, Archedemos from Thera is known to have built a cavesanctuary and cultivated a garden for the Nymphs on Mount Hymettos overlooking the modern town Vari in Attica. An abundance of votive offerings has

${ }^{2}$ Mitford (1980), SEG 30, 1608.

${ }^{3}$ Recently one more item (an amphora dated to 224/3 B.C.) has been published by HERMARY (2006), adding to the 309 items published by MITFORD (1980).

${ }^{4}$ But new texts from Paphos published in Michaelidou-Nikolaou (1993) lower the date further to the mid-second to the first centuries B.C.

${ }^{5}$ Existing scholarly discussions of the material in the early 1980s concentrate mainly on the meaning of particular words or phrases in the inscriptions: e.g. ROBERT (1981), no. 636, BINGEN (1982), POUILloux (1982), MASSON (19832 [1961]). The Kafizin dossier is absent from the recent Kernos Suppl. volume by PRÊTRE et al. (2009) on dedications.

${ }^{6}$ The figure 268 is that given by MiTFORD (1980), p. 259, to which I add the one published by Hermary (2006) (see n. 3).

${ }^{7}$ Joint dedications: e.g. Kafizin, nos. 60, 121, 137.

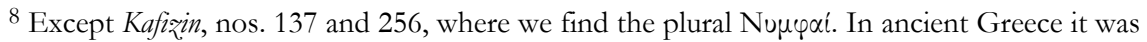
more common to address the Nymphs in the plural.

9 The inscriptions date from the 23rd year of Ptolemy III Euergetes to the $4^{\text {th }}$ year of Ptolemy IV Philopater. On the chronological distribution of the dedications in this eight-year period where the year is indicated, see MITFORD (1980), p. 272-273. 
been found; ${ }^{10}$ and the inscriptions in the cave describe his efforts undertaken at this site. ${ }^{11}$ One of them describes Archedemos as a man seized by the Nymphs (nympholeptos), who 'fashioned the cave at the directions of the Nymphs':

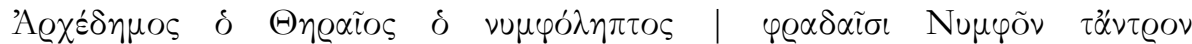
ध $\xi \eta \varrho \gamma \alpha \dot{\alpha} \alpha \tau o .{ }^{12}$ Archedemos may be compared to Pantalkes, who devoted his life to the service of the Nymphs and other divinities, decorating a grotto near Pharsalos in Thessaly in perhaps the fourth century. ${ }^{13} \mathrm{~A}$ similar kind of personal piety is seen in Artemidoros, son of Apollonios, of Perge in the third century. He founded a shrine in Thera and furnished it with rock-cut inscriptions, reliefs, niches, altars, statues and other dedications for a wide variety of divinities. ${ }^{14}$ If it is correct to think that the some 270 items of pottery were Onesagoras' own dedications, might he similarly have been a nympholept who was 'seized by the Nymph'?15

Our knowledge of Onesagoras depends entirely on the information revealed in the dedicatory inscriptions. Unfortunately, most of the inscriptions are fragmentary and involve numerous textual uncertainties, and many of Mitford's restorations are potentially misleading. A useful way into the dossier is to look at the few completely or better preserved inscriptions that survive:

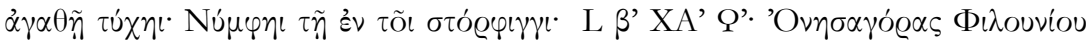

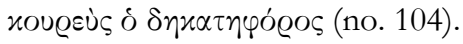

With good fortune; to the Nymph on the conical hill; the second year (221/220 B.C.); ${ }^{16}$ Onesagoras, son of Philounios, barber, the dekatephoros.

\footnotetext{
10 These probably came not only from Archedemos, but also other worshippers visiting the cave (see the following note).

11 IG I3 977-980; Weller (1903), CONNOR (1988), p. 166-174, BONNECHERE (2001), p. $37-$ 41. HimmelmANN-WiLDSCHÜTZ (1957), p. 9, argued on epigraphic grounds that not all of them were inscribed by Archedemos himself.

${ }^{12} I G \mathrm{I}^{3} 980$

13 SEG 1, 247-248; 2, 357; 3, 476; 16, 377-378; CONNOR (1988), p. 162-163, BONNECHERE (2001), p. 34-37.

14 IG XII 3, 421-2, IG XII 3 Suppl., 1333-1350; van Straten (1976), p. 18, Palagia (1992), GRAF (1995), p. 107-112. Several other individuals who were nympholeptoi or theoleptoi have left traces in literary and epigraphical evidence: see the sources in HimMELMANN-WILDSCHÜTZ (1957),

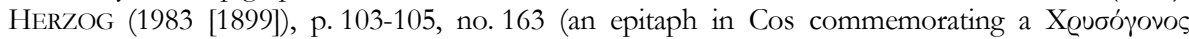
$\mathrm{N}<u v>\varphi \tilde{\omega} \nu \lambda \dot{\alpha} \tau \varrho \iota \varsigma$ in second/third century A.D.).

15 This has been suggested by MitFord (1980), p. 261, ROBERT (1981), p. 476, CONNOR (1988), p. 164, Pache (2011), p. 55-69, cf. Bingen (1982), p. 171. On Nympholepsy, see HimmelmanNWILDSCHÜTZ (1957), VAN STRATEN (1976), p. 18-20, BORGEAUd (1979), p. 159-162, VAN STRATEN (1981), p. 79, 95, CONNOR (1988), SOURVINOU-INWOOD (2005), p. 109-111, VERSNEL (2010), p. 119-121, 125-130, PACHE (2011).

${ }^{16} \mathrm{~L} \beta^{\prime} \mathrm{XA}$ ' Q" apparently signifies the second ( $\beta^{\prime}$ ) year of the reign of Ptolemy IV Philopater, $221 / 0$ B.C., which corresponds to the $90^{\text {th }}(\mathrm{Q}=90)$ year of the Citium era initiated in $311 / 0$ B.C. See the explanation in MITFORD (1980), p. 77-78, 251-252, index 4. The chronology he established is accepted by MASSON (1981), 626-627 and other scholars.
} 


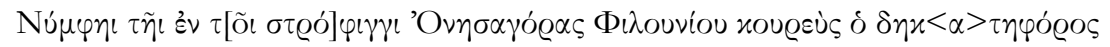

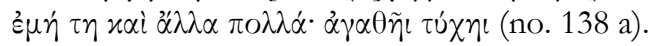

To the Nymph in the conical hill, Onesagoras, son of Philounios, barber, the dekatephoros, (dedicated) me and many others; with good fortune.

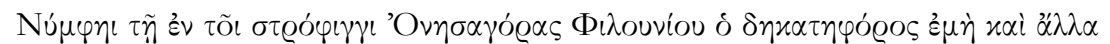
$\pi \circ \lambda \lambda \dot{\alpha} \tau \dot{\alpha} \delta \varepsilon \varepsilon<\dot{0}>\chi \alpha \dot{\alpha} \varrho \tau \tau \alpha \cdot \alpha \gamma \alpha \theta \tilde{\eta} \iota \tau \dot{\chi} \chi \eta \iota$ (no. 138 b).

To the Nymph in the conical hill, Onesagoras, son of Philounios, the dekatephoros, (dedicated) me and many other thank-offerings here; with good fortune.

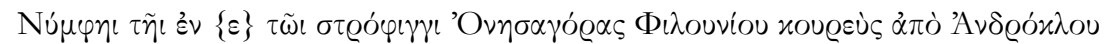

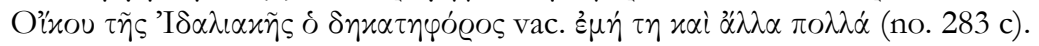

To the Nymph in the conical hill, Onesagoras, son of Philounios, barber, from the oikos of Androklos of the territory of Idalium, the dekatephoros (dedicated) me and many others.

As these examples demonstrate, the standard elements in Onesagoras' dedicatory inscriptions include the phrase $\alpha \gamma \alpha \theta \tilde{\eta} \tau \dot{n} \chi \eta \iota$, the divine recipient (the

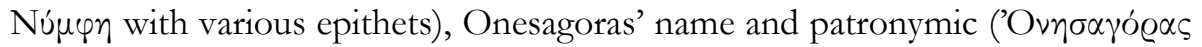

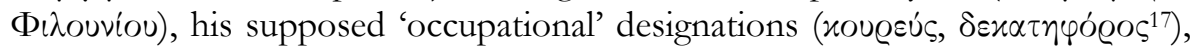

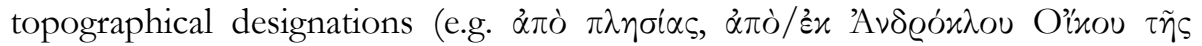
'I $\delta \alpha \lambda \iota \alpha x \tilde{\eta} s$ ), and occasionally the year in the Ptolemaic era (e.g. L $\beta$ ' XA'). Sometimes (but not in the examples above) they also mention the source of

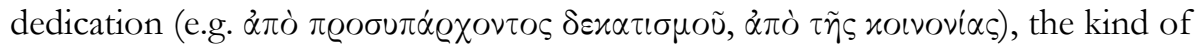
vessel dedicated, and the name of the potter ( $\left.\varkappa \varepsilon \propto \alpha \mu \varepsilon^{\prime} \varsigma\right)$ who made it. However, the exact relations between these elements remain largely uncertain. These inscriptions vary in length; some of them were incised on the vessels before firing, others afterwards. There are no identifiable trends governing which ones were inscribed before or after firing; but the fact that a lot of them were inscribed before firing seems to suggest that they were specially commissioned in anticipation of dedication rather than 'raw' vessels normally used for other purposes. Apart from inscriptions, some of the vessels carry decorations of human heads, plants, and other patterns. ${ }^{18}$ For example, no. 266 depicts a schematic frontal head with features roughly incised and flanked by foliage; it is not sophisticated but is certainly lively (Fig. 1).

Fig. 1. Drawing of the fragmentary pitcher Kafizin no. 266, after Mitford (1980), p. 200.

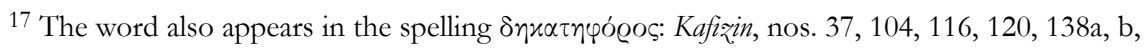
153, 251.

${ }^{18}$ E.g. Kafirin, nos. 262, 264, 274, 290, 291, 292.
} 


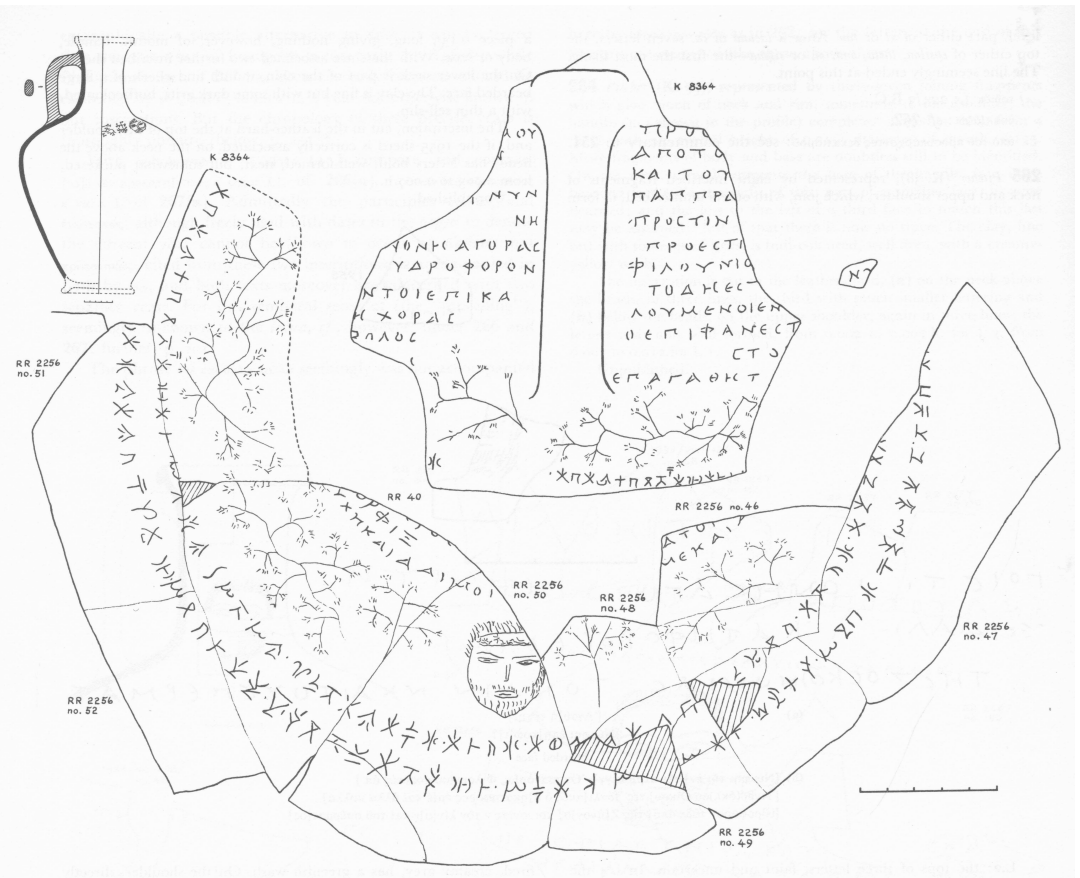

In many inscriptions, this Nymph is qualified by the description $\varepsilon$ $v$ õ

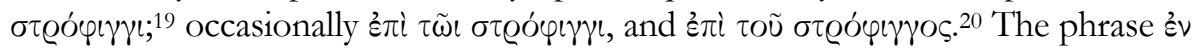
$\tau$ õ $\sigma \tau \varrho o ́ \varphi \imath \gamma \gamma \iota$ is uniquely attested at Kafizin, and is generally understood by modern scholars to be referring to the 'conical hill' or the 'sharp, pointed hill', the hill at Kafizin where the cave-sanctuary was situated, and also the spiral route that one had to follow to reach its summit. ${ }^{21}$ The circular imagery might also relate, not to the hill, but to divination: the Nymphs are often depicted as seated on a circular throne; some terracotta figures represent them as dancing or seated in a circle with Pan in the middle. Some scholars think that the whirling movement is

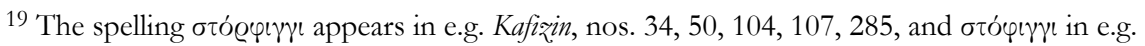
Kafizin, nos. 14, 305.

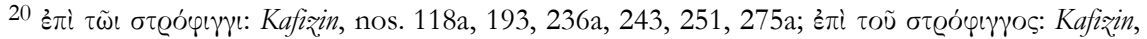
nos. 237, 259, 286.

21 Mitford (1980), p. 262: 'upon the Spear Butt or the Pointed Hill'; MASON (1981), p. 634:

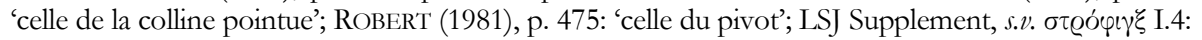
'applied to the conical hill at Kafizin in Cyprus'. Mitford (1980), p. 15, no. 14, thought that the name of the hill $\Sigma \tau \varrho o ́ \varphi v \gamma \xi$ 'is clearly the Cypriot form of $\sigma \tau \operatorname{có} \theta 0 \gamma \xi$, tyne of an antler, spike, tusk, a tongue of land'. However, HADJIOANNOU (1982), p. 255, suggests that the word is more appropriately related to $\sigma \tau \varrho o ́ \varphi v \gamma \xi$ etymologically. LSJ, s.v. $\sigma \tau \varrho o ́ \varphi v \xi \xi$. I: 'pivot or axle or pin on which a body turns'. Accordingly HADJIOANNOU explains $\sigma \tau \varrho o ́ \varphi(\gamma \xi$ as 'the hill of which the ascent is a zig-zag path up the hillside, i.e. the hill up to which one goes turning hither and thither'. Similarly KARAGEORGHIS (2005), p. 251, says: 'the hill on which she had her sanctuary was called Strophynx, no doubt because of the spiral route which had to be followed to reach the top'. 
symbolic of the divinatory power of the Nymphs.22 The presence of this sanctuary at Kafizin is interesting as the cult of a Nymph or the Nymphs is hardly known elsewhere in Cyprus. There is piecemeal evidence that a Nymph was probably also worshipped at Chytroi, Troulloi and Tamassus; but the evidence is not substantial. ${ }^{23}$ In other parts of Greece the worship of the Nymphs is much more common. ${ }^{24}$ Perhaps because of the Nymphs' association with natural features and landscape (such as mountains, the sea, springs, rivers and trees), their cults were frequently located in caves or springs. ${ }^{25}$ As Mitford pointed out, the

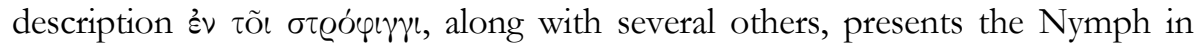
question as primarily a mountain Nymph or an Orestiad: she was also ỏ@eovó $\mu$ o

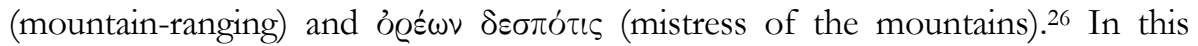
dossier, she is also frequently described as Nú $\mu \varphi \eta$ 'A $\delta \varepsilon \lambda \varphi \eta^{\prime} .{ }^{27}$ Two inscriptions have a doubtful and disputed reference to $\theta u \gamma \alpha \dot{\alpha} € \varrho ; 28$ but Mitford's restorations are uncertain. It is unparalleled and inconceivable in Greek religion for a mortal to address a goddess as his daughter.

22 On the material evidence, see PASQUIER (1977), LARSON (2001), p. 236-238, BONNECHERE (2003), p. 253-262. On the possible link with divination, see BONNECHERE (2001), p. 38-43, BONNECHERE (2003), esp. p. 255-258.

23 Chytroi: Myres (1914), p. 547, no. 1900; Troulloi: RDAC (1968), p. 78, no. 11; Tamassus: Mitford (1958), p. 266-274; discussed in MitFord (1980), p. 261; followed by KARAGEORGHIS (2005), p. 251. On religion of ancient Cyprus, see e.g. Hill (1940), ch. 4, p. 55-81, KarAGEORGHIS (1998), KARAGEORGHIS, MATTHÄUS and RoGGE eds. (2005).

${ }^{24}$ On the cult of the Nymphs in ancient Greece, see PArKer (1996), p. 165-167, 233, HALMTISSERANT and SIEBERT (1997), p. 891-902, with extensive bibliography on p. 891-892, LARSON (2001), SOURVINOU-INWOOD (2005), p. 103-116.

25 Caves that hosted the cult of the Nymphs were broadly distributed in different parts of the Greek world: see Hom., Od. XIII, 103-108, MitFord (1980), p. 261, AMANDRY (1984), esp. p. 40311, PARKER (1996), p. 165-167, LARSON (2001), p. 226-258, SOURVINOU-INWOOD (2005), p. 103.

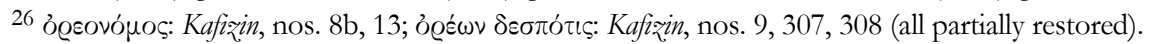
Discussed in MiTforD (1980), p. 262. The word ógeovónos is also used (not of the Nymphs specifically) in e.g. Eur., HF, 364, Theophr., Hist. Pl. IX, 18.3, Anth. Pal. VI, 107. Some deities are associated with mountains and have the epithet ó@eıs / $\alpha$, such as Meter Oreia (IG XII 7, 75, SEG 6, 718, SEG 41, 1329), Aphrodite Oreia (in EKMAN [1937], p. 626, no. $12=$ BE 1942, no. 179), and

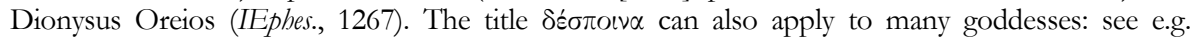

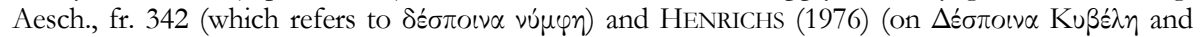

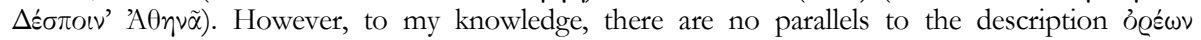
$\delta \varepsilon \sigma \pi$ ótıఢ being used for a goddess. On mountain nymphs (orestiades), see LARSON (2001), p. 9.

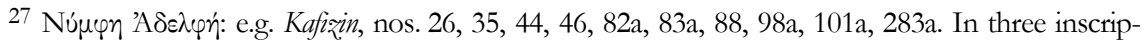
tions the goddess appears to be addressed as Onesagoras' own sister ( $\left.\alpha \dot{u} \tau o \tilde{u} \alpha \delta \varepsilon \lambda \varphi \eta^{\prime}\right)$ according to MiTFORD's doubtful restorations: Kafizin, nos. 48, 194, 213d; but all of them are fragmentary and the supplements are disputed. Scepticism has been expressed by ROBERT (1981), p. 475, HADJIOANNOU (1982), p. 258-259, POUILloux (1982), p. 102-103, Hermary (2006), p. 68-69.

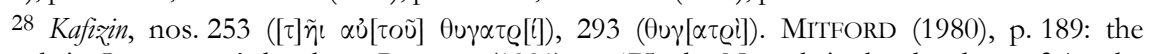
Nymph is Onesagoras' daughter; ROBERT (1981), p. 475: the Nymph is the daughter of Agathe

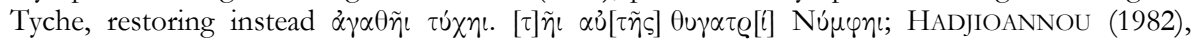
p. 259: Onesagoras' physical daughter, not the Nymph is meant. Equally doubtful is the reference to $\mu \nu \eta \sigma \tau$ ' and whether the word can be applied to the goddess. 
The cult of the Nymph at Kafizin seems to concern in an obscure way not only Onesagoras but also a koinonia or two koinoniai. Unfortunately all the inscriptions mentioning this are fragmentary. A relatively better preserved text reads:

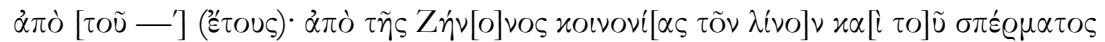

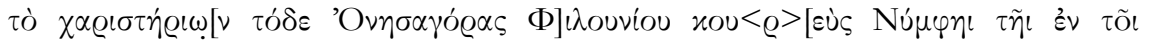

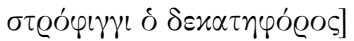

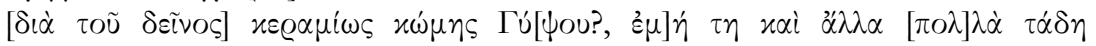

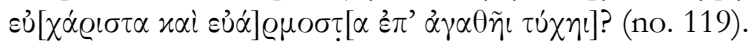

from [the ...] (year); from the koinoni[a] of Zen[o]n, [the one (involved in) fla]x and linseed, [this] thank-offering [Onesagoras, son of Ph]ilonios, barb[er], (dedicated?) [to the Nymph in the conical hill, the dekatephoros], [through someone], ${ }^{29}$ a potter, of the village of Gy[psos?, m]e and [ma]ny other than[k-offerings and approp] riate gifts here, [with good fortune]?

Sometimes the inscriptions refer to Zenon's koinonia, but elsewhere to Androklos' koinonia and Androklos' oikos. ${ }^{30}$ It is not certain whether they were one koinonia or two independent koinoniai, and what the precise relations (if any) between Zenon and Androklos were. Based on several inscriptions which refer

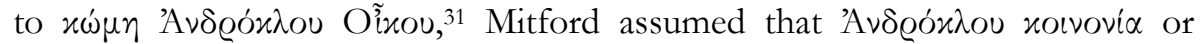

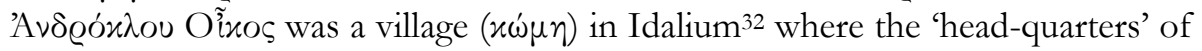
Zenon's koinonia was located. In other words, he took the two koinoniai as the same; but his interpretation is far from certain. ${ }^{33}$ As we shall see later, the koinonia (or koinoniai) appears to be involved in some way in flax and linseed; and Mitford spoke of it as a 'commercial company' and a 'tax-farming' association involved in the collection of taxes on flax and linseed. ${ }^{34}$

There are reasons to think that the koinonia (or koinoniai), apart from being a 'commercial organization' (in Mitford's view), was also a religious association actively involved in the worship and perhaps maintenance of this cult, and that it met occasionally for drinking parties and small-scale celebrations possibly

29 Apparently the word $\delta \iota \dot{\alpha}$ followed by a genitive in the Kafizin dossier can denote the agent through which a vessel was fabricated and/or dedicated. Mitford thought that in no. 119 the potter (whose name is not preserved) was both the fabricant and the agent through which Onesagoras performed the act of dedication; but his interpretation remains uncertain.

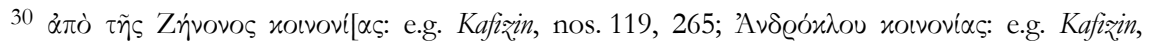

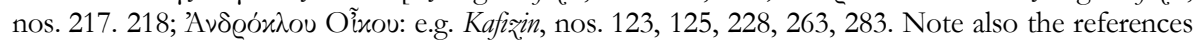

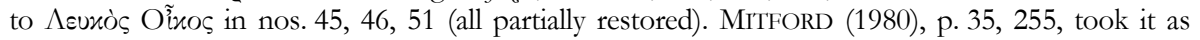
signifying perhaps an estate or farm in modern Kefkoniko; but he did not explain the relation (if any) between Leukos' oikos and Androklos' oikos.

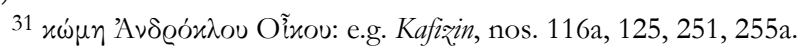

32 MITFORD (1980), p. 253, noted that no less than 15 inscriptions (but some of them are doubtfully restored) describe Androklos' oikos explicitly as $\tau \tilde{\eta} \varsigma$ 'I $\delta \alpha \lambda \iota \alpha x \tilde{\eta} \varsigma$. See e.g. Kafiæin, nos. $263 b$

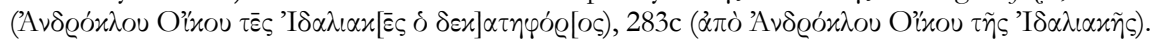

33 MitFord (1980), p. 86, 254.

34 MitFord (1980), p. 256-8. 


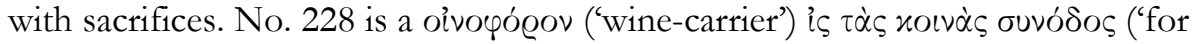
the common reunions'). The reunions are likely to be religious occasions celebrated by members of the koinonia (or koinoniai). ${ }^{35}$ Apart from the oivoyógov, it has been suggested that the $\theta$ neix $\lambda \varepsilon \iota \varsigma$ was also used in a ritualized drinking

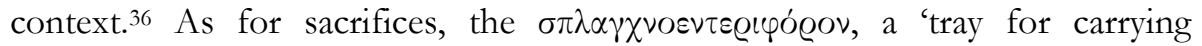

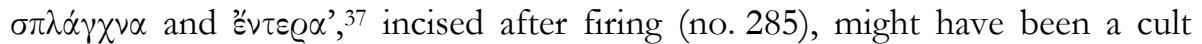
utensil used in sacrifices during similar religious reunions. We have a dedication

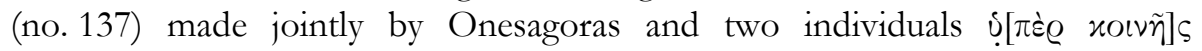

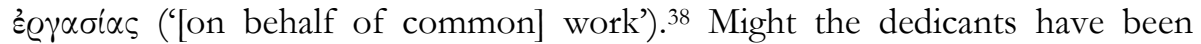
members of the association(s) praying to the Nymph for the prosperity of their trade? Despite the close connection between the cave-sanctuary and the association(s), we do not know whether the Nymphaeum was established by this group(s) and whether the Nymph's worship was exclusive to its members. Nor can we establish with certainty the nature of the association(s) and its connection with Onesagoras. The fact that Onesagoras described himself as

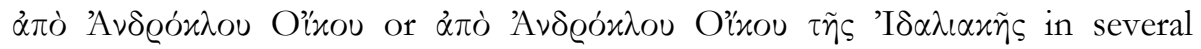
inscriptions indicates that he was a member of the koinonia (or koinoniai). ${ }^{39}$ Another hint comes from the human heads carved on some of the vessels: 40 most of these depict a single bearded face, probably a self-portrait of Onesagoras himself; 41 but in a few cases a bearded head appears alongside smaller heads without beards, representing perhaps other members of the

35 ROBERT (1981), no. 636, p. 476, compared this reunion to 'les beuveries de village ou d'association dans les inscriptions de Mysie et Bithynie et d'ailleurs, où le vin joue un grand rôle'.

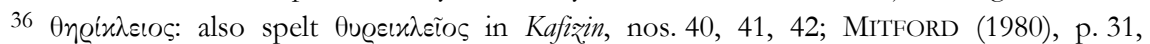
explained it as 'a vase of an excellence worthy of the famous Corinthian potter Therikles'. Athen., XI, 470e-472e; MaLFitANA (2004); SEG 54, 1534.

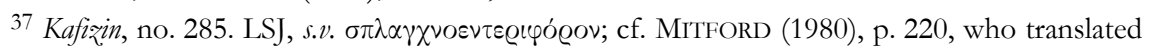
the word as 'meat tray'. Note that MITFORD also identified Kafiqin, nos. 286 and 287 as $\sigma \pi \lambda \alpha \gamma \chi \chi^{\nu 0-}$

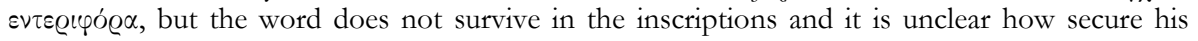
identification is.

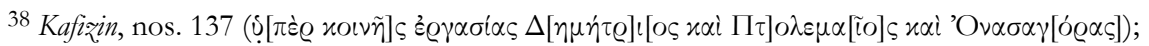

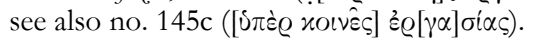

39 E.g. Kafizin, nos. 125, 228, 263b, 283c. Note, however, that in the evidence available

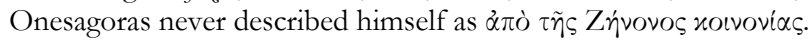

40 The use of self-portraiture seems to be a feature shared by several theolepts: Archedamos seems to have carved a self-portrait of himself in the cave at Vari: a slightly more than life-size figure holding stone-working tools is depicted, and the name Archedamos is cut twice next to his head: IG I3 979, WeLLER (1903), p. 271-3, fig. 6, ConNor (1988), p. 166. Artemidoros of Perge too carved an image of himself, a head with a laurel surrounded by a circular inscription IG XII 3 Suppl., 1348, with figure on p. 296, in the shrine he founded in Thera. On the use of selfportraits as a sign of nympholepsy, see LARSON (2001), p. 16.

41 The bearded heads are taken as probable self-portraits of Onesagoras by e.g. MASSON (1981), p. 631, ConNor (1988), p. 164, PACHE (2011), p. 66. Cf. HERMARY (2006), p. 71, who thinks that the five bearded faces on the newly published vase represent participants in the

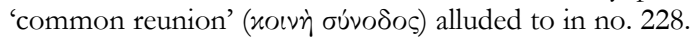


association(s). ${ }^{42}$ It is tempting to see Onesagoras as a leading or influential member of the group(s), charged with the religious duty of bringing dedications to the Nymph on behalf of his associates (see below), perhaps in fulfillment of some vow made collectively by the koinonia (or koinoniai); but this remains a conjecture. These institutional uncertainties present one of the greatest impediments to our understanding of Onesagoras and the dossier at Kafizin. What is more or less certain is that this was a local sanctuary maintained by the initiative and at the expense of individuals or a small group(s), and one wonders whether it belonged to some genos or a private association. In any case, the cult at Kafizin was evidently a focus of religious activities to Onesagoras' circle(s) of associates, but it is unclear whether it was also open to other worshippers.

There is evidence to suggest that pottery was an economic activity in the area around Kafizin. Some of the vessels in the dossier were dedicated by potters, ${ }^{43}$ the most prominent one being Demetrios, son of Kallikles, from Tamassus, located some eleven miles to the west of Idalium. He is known to have dedicated at least seven items of vessels to the Nymph, appearing in these inscriptions more frequently than any other does, with the exception of Onesagoras. ${ }^{44}$ Another potter, Aristagoras, in no. 290, is known to have brought a dedication to Kafizin. ${ }^{45}$ So prominent is Demetrios, son of Kallikles, that Mitford took him as a partner (koinonos) of Onesagoras in the same koinonia. ${ }^{46}$ Some examples of his dedicatory inscriptions are as follows:

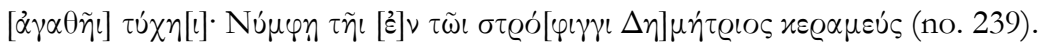

With good fortune; to the Nymph in the coni[cal hill, De]metrios, a potter, (dedicated).

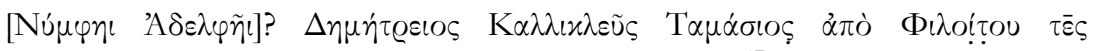

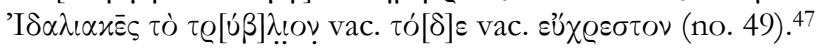

[To the Nymph Sister]? Demetrios, son of Kallikles, of Tammassus, from Philoitos of the territory of Idalium, (dedicated) th[is] useful bo[w]l.

42 One bearded head: Kafizin, nos. 262-266; a bearded head with smaller heads without beards: Kafizin, nos. 262(?), 271, 274; five bearded heads of similar sizes: HERMARY (2006), p. 66, fig. 4. MITFORD (1980) thought that no. 271 has a small female face; but from his drawing it is hard to tell whether it is male or female.

43 On potters and their pots, see MiTFORD (1980), p. 255, 259-60.

44 Demetrios' dedications: Kafizin nos. 49, 50, 62, 130, 239, 242, 278. MitFord (1980), p. 162, identified as many as fourteen items dedicated by Demetrios, but I have omitted here the ones too fragmentary for the identification to be secure.

45 Kafizin, no. 290.

46 MitFord (1980), p. 259.

47 Mitford (1980), p. 39-40, suggested that Philoitos, a village or property in the territory of Idalium, signifies 'not the domicile of Demetrios, but - as commonly in these inscriptions - the locality out of the revenues of which the dedication was made'. 


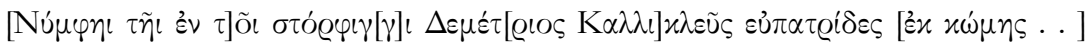

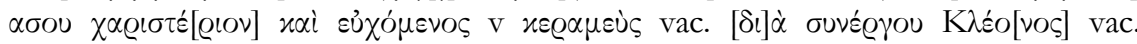
$\mathrm{M}[\nu \alpha \sigma \varepsilon ́]$ ou? (no. 50). ${ }^{48}$

[To the Nymph in the] conical hill, Demet[rios, son of Kalli]kles, of noble family, [from the village . .] astos (dedicated) as a thank-offering and as a vow, the potter, through a co-worker Kleon, son of M[nase]as?49

However, the word $x \varepsilon \varrho \alpha \mu \varepsilon u ́ s$ in the Kafizin corpus can refer to potters as fabricants of the pots being dedicated as well as potters as dedicators. Where the word $\varkappa \varepsilon \varrho \alpha \mu \varepsilon u ́ s$ appears in vessels inscribed with Onesagoras' name, it never refers to Onesagoras himself but to someone else, most probably the maker of

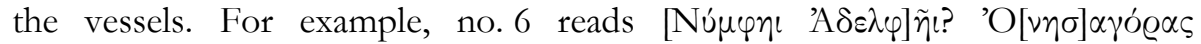

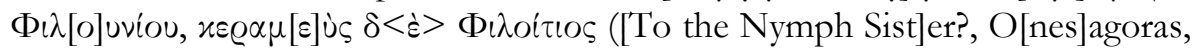
son of Phil[o]unios, potter Philoitios); and no. 63: [Nú $\mu] \varphi \eta \iota$ 'A $[\delta \varepsilon \lambda \varphi \tilde{\eta}$

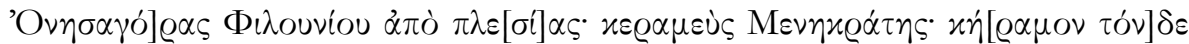
$\tau \dot{v} \chi \eta \iota \dot{\alpha} \gamma \alpha \theta \tilde{\eta} \iota$ ([To the Nym]ph S[ister, Onesago]ras, son of Philounios, from the neighbouring area; potter Menekrates; [this] ve[ssel], with good fortune). Despite Onesagoras' possible connection with potters, there is no evidence that he was a potter who dedicated his own wares to the Nymph. ${ }^{50}$ Where the ethnic or toponymic of some of the potters (as fabricants) have survived,

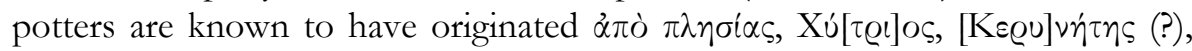
$x \omega \dot{\mu} \mu \eta \Gamma \dot{v}[\psi \circ u]$, and perhaps $\Phi \iota \lambda \circ \iota \tau \circ \varsigma \tau \tilde{\eta} \varsigma$ 'I $\delta \alpha \lambda \iota \alpha x \tilde{\eta} \varsigma .{ }^{51}$ Pottery is thus prominent at the shrine in three ways: most of the objects dedicated are ceramic, often of unusual form; potters dedicate; potters are mentioned in dedications made by others. The reason for this prominence, however, is unclear.

It is uncertain whether the koinonia (or koinoniai) was involved in pottery production itself. Nor do we know if these potters - whether as dedicants or fabricants - were connected with the koinonia (or koinoniai); and if so, in what ways. As will become apparent shortly, the association(s) was engaged in the

48 The word $\varepsilon \dot{\pi} \pi \alpha \tau \varrho^{i} \delta \eta \varsigma$ suggests that Demetrios claimed to be well-born: see HADJIOANNOU (1982), p. 257, cf. MiTFORD (1980), p. 162, no. 219.

49 It is unclear whether Kleon was the agent through which the vessel was fabricated or dedicated. MiTFORD (1980), p. 41, envisages both possibilities: 'Demetrios, himself a potter, has engaged a colleague, if not to fabricate this pot, certainly to perform the act of its dedication'. There are a few instances where the fragmentary nature of the texts renders it uncertain whether the appearance of the word $x \varepsilon \varrho \alpha \mu \varepsilon u ́ s$ (whether partially or completely preserved) signifies a dedicator or a maker: Kafizin, nos. 119, 121, 264, 302.

50 Cf. LATTE (1955), p. 194-5: 'Die Inschriften sind ... vor dem Brande eingeritzt. Das erklärt sich am einfachsten, wenn er selbst Töpfer war and nun seine Ware in natura der Nymphe weihte'. Latte did not have access to the whole corpus of the materials at the time of writing; from MITFORD's publication it is clear that some inscriptions were inscribed after firing.

51 åjò $\pi \lambda \eta \sigma i \alpha$ s: Kafizin, nos. 64, 68, 81, 91, 296. Unfortunately the others are all partially or

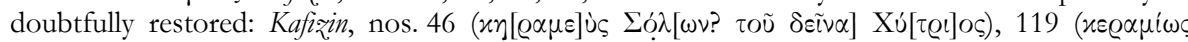

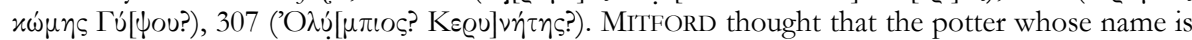
Philoitios (nos. 7, 22, 60) might come from the place $\Phi \iota \lambda$ oi $\tau o \varsigma ~ \tau \bar{\varepsilon} \varsigma$ 'I $\delta \alpha \lambda \iota \alpha \varkappa \bar{\varepsilon} \varsigma$ mentioned in no. 49. 
cultivation or trading of flax and linseed. One would like to know what connection (if any) there was between flax cultivation and pottery, and whether the association(s) was simultaneously engaged in both kinds of economic activities. Mitford concludes that potters and 'tax-farmers' (on this idea see below) formed a commercial enterprise, and that 'the profits [of Zenon's koinonia] were ploughed back into the manufacture of pots on this massive scale', with the advantage being that 'the company could thus operate throughout the year. Its activity was not confined to a short season, and a fluctuating harvest'; 52 but this remains speculative. What the evidence suggests is a possible connection between Onesagoras and some potters, but their precise relation is difficult to pin down.

While there is no evidence that Onesagoras was a potter, it is more or less certain that he was a barber: the word novgeús recurs in many inscriptions

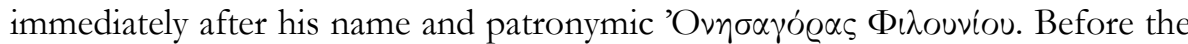
whole dossier was published in 1980, the word was (mis-)interpreted as a deme name from the territory of Idalium, ${ }^{53}$ or a variant of the city-ethnic of Kourion KovQıús. ${ }^{54}$ Mitford's full publication made available new evidence which shows that the word indicates almost certainly a trade or craft: an inscription no. 227

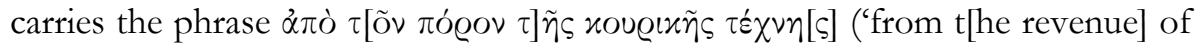
barber trade'), and another no. 117 b speaks of Onesagoras as being appointed

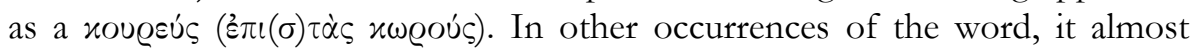
always qualifies the name Onesagoras, signifying his trade and possibly the source of the dedications to the Nymph. ${ }^{55}$ By comparison with similar offices in the cults in other parts of Cyprus, Phoenicia and Syria, some scholars have taken him as a temple-barber. ${ }^{56}$ Yet there is no reason why Onesagoras could not have been an ordinary artisan in the barber trade: ${ }^{57}$ that a sacred barber is possibly attested in fourth-century Citium does not preclude the presence of ordinary barbers at Cyprus. The case cannot be proved either way.

Barber trade aside, Onesagoras was engaged in at least one other activity, namely the cultivation or trading of flax and linseed. That Onesagoras' and/or

52 Mitford (1980), p. 227, 259. Pilides (2004) thinks that MitFord's conclusion may be supported by the mixed economical activities (pottery and weaving) attested by archaeological evidence at the hill of Agio Georgios in Nicosia, some four miles away from Kafizin.

53 MitFord (1950), p. 102.

54 Bernand and MASSON (1957), no. 29, p. 36, MASSON (19832 [1961]), 253, n. 4. The

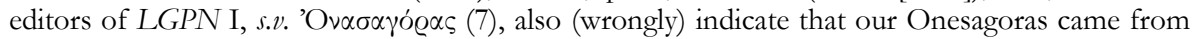
the city Kourion.

55 Cf. other occurrences of 'job descriptions' in private dedicatory inscriptions are e.g. IG $\mathrm{I}^{3}$

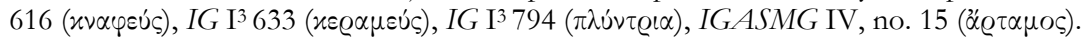

56 E.g. CISem I, 86 (a) (Citium, fourth-century B.C.), DOHAN and KENT (1926), p. 249-256, esp. p. 254, MiTfORD (1980), p. 261-262. See also LSJ Supplement, s.v. xovgeúc I.1b: 'app. as title of official, Kafizin 117b, 118b, al.' MITFORD (1980), p. 261-262, suggested that this sacred office was connected to the cult of Apollo Amyklaios at Idalium, and not to the Nymph at Kafizin; but Pouilloux (1982), p. 101, considers the latter as more probable.

${ }^{57}$ Doubts have already been expressed by Bingen (1982), p. 170, Poulloux (1982), p. 100. 
the association(s)'s income was related to flax and linseed is indicated by such

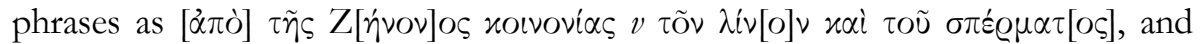

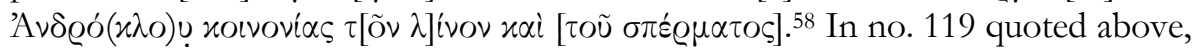
the dedication is described as a 'thank-offering, from Zenon's koinonia (involved

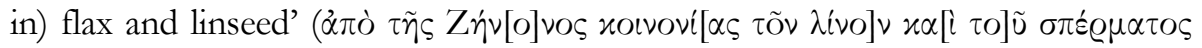

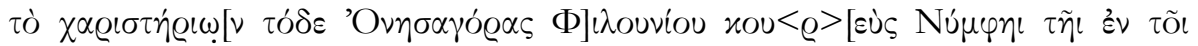

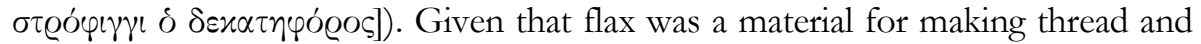
cloth, and its seed for linseed oil, Onesagoras and the association(s) were probably engaged in some sort of linen and oil production or trade. ${ }^{59}$ It is perhaps in connection with these agricultural produce that the phrase $\dot{\alpha} \pi \dot{o} \pi \varrho 0 \sigma u \pi \dot{\alpha} \varrho \chi O \nu \tau O \varsigma$ $\delta \varepsilon \varkappa \alpha \tau \iota \sigma \mu o \tilde{u}$, found in some of the dedicatory inscriptions, is to be understood. 60 For example, no. 266 b speaks of $\dot{\alpha} \pi \dot{o} \tau \tilde{\omega} \iota \pi \varrho O \sigma \varphi<\pi \dot{\alpha}>\varrho \chi O(\nu) \tau \iota \delta \varepsilon x \alpha[\tau \iota] \sigma \mu \tilde{\omega} \iota \dot{\alpha} \pi \dot{o}$

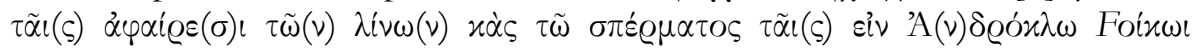
('from the additional tithe from the takings of flax and linseed, the ones in the oikos of Androklos'). ${ }^{61}$ If it is correct to understand the phrase to mean 'from an additional tithe', ${ }^{2}$ it would point to some unexpected income, from which the dedications were made. If we accept that agriculture was a major source of income for Onesagoras and the association(s), it is possible that $\alpha \pi \dot{o} \pi \varrho 0 \sigma u \pi-$ $\alpha \varrho \chi O \nu \tau o \varsigma \delta \varepsilon x \alpha \tau \iota \mu \tilde{u}$ indicates an exceedingly bountiful harvest of flax. It is interesting and baffling that Onesagoras had multiple professions: he seems to be simultaneously involved in the barber trade and the production or sale of flax and linseed. 63 Accordingly, we are presented with the possibility that the dedications were made from the earnings of more than one economic activity.

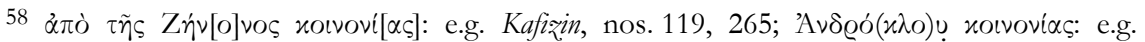
Kafizin, nos. 217. 218.

59 The cultivation of the two commodities in modern Cyprus is discussed in STORES and BRIEN (1930), p. 177, MITFORD (1980), p. 257.

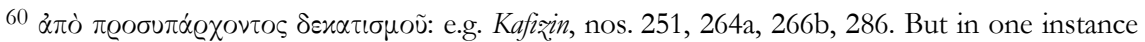
no. 256, we find $[\dot{\alpha} \pi] \dot{\partial} \tau O \tilde{u} \delta \varepsilon \varkappa[\alpha \tau \iota] \sigma \mu O \tilde{u}$.

61 The use of apo with the dative in the Cypro-Arcadian dialect is explained in MITFORD (1980),

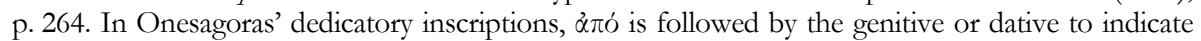
the place of origin, the source of dedication, or the year. See also MITFORD (1980), p. 275, index 7, s.v. ঝेó.

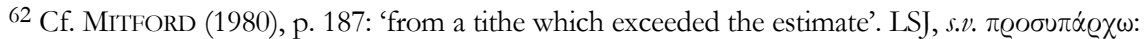

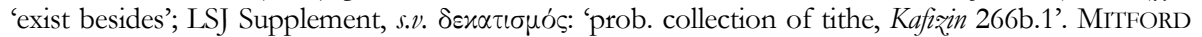
(1980), p. 287, n. 1, noted that the phrase is 'on the evidence available confined to the first two years of the company's activity'.

63 Apart from barber trade and flax cultivation or trade, a third profession has been associated with Onesagoras, but on rather tenuous grounds. Kafizin, no. 258b has a possible but

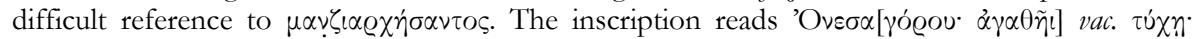
$\mu \alpha \nu \zeta \_\alpha \eta_{\eta} \sigma \alpha \nu \tau O \varsigma$, and may be translated as 'with good fortune; when Onesa[goras] was a

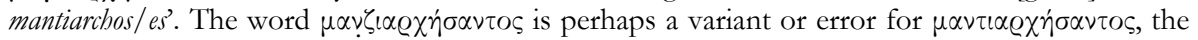
aorist participle of the otherwise unattested verb $\mu \alpha v \tau \iota \propto \varrho \chi \varepsilon$ é Accordingly, it has been suggested

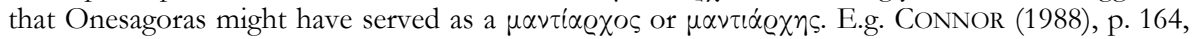
infers from this unusual word that Onesagoras might have had a prophetic role, as is known to have been the case with some nympholepts. However, the single appearance of this otherwise 
About ten of his surviving offerings are described as $\chi \alpha \varrho \iota \sigma \eta \dot{n} \varrho\llcorner$ or 'thankofferings'. ${ }^{64}$ This is noteworthy as the word seldom appears in dedicatory inscriptions before the third century. Onesagoras' usage is among the earliest applications of the word in dedications by private individuals. ${ }^{65}$ Unfortunately we are not told what good tidings occasioned these charisteria. Only in one instance is the word charisterion accompanied by further information: no. 119 (quoted above) speaks of the object as a 'thank-offering from Zenon's koinonia (involved in) flax and linseed'. If it is correct to understand this as a thankoffering from Zenon's koinonia for the flax and linseed harvested or sold, this was perhaps offered to give thanks to the goddess for the proceeds collected while at the same time hoping for continual success in the future.

There remains for us to consider the meaning of the recurring word $\delta \varepsilon \varkappa \alpha \tau \eta \varphi o ́ \varrho o s$ with which Onesagoras described himself, a word crucial to our understanding of Onesagoras and the dedications. The word can mean 'tithereceiving' or 'tithe-paying' depending on the context. Apollo has the epithet $\delta \varepsilon x \alpha \tau \eta \varphi$ óos, meaning 'tithe-receiving'. ${ }^{66}$ On the other hand, the aparchai sent to Apollo at Delos from different parts of the Greek world are qualified with the

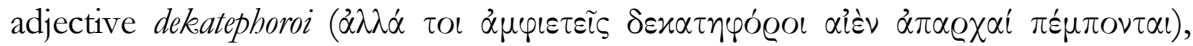
literally meaning "tithe-paying aparchar. ${ }^{67}$ The Kafigin inscriptions aside, ${ }^{68}$ it is

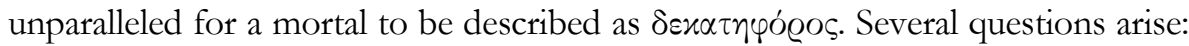
was Onesagoras 'tithe-paying' or 'tithe-receiving', and what was the nature of the dekate/ai (if any) involved? The simplest explanation is that Onesagoras was 'bringing a tithe' to the Nymph using his income, ${ }^{69}$ which came from his rovewǹ

unknown verb in an incomplete inscription makes this interpretation highly uncertain. See MitFord (1980), p. 194, no. 258, ROBERT (1978), SEG 28, 1299, ROBERT (1981), no. 636, p. 476;

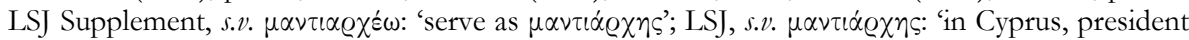
of a college of $\mu \dot{\alpha} \nu \tau \varepsilon เ \zeta^{\prime}$.

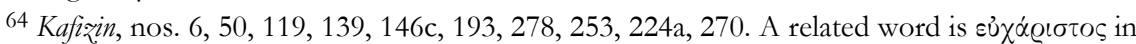

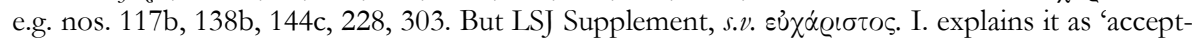
able gifts, Kafizin 117b, 303', not 'thank-offerings'.

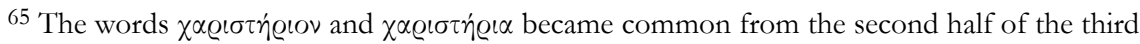
century B.C. in victory dedications of the Attalids: e.g. OGIS 269, 273, 280, 328. In literary sources, on the other hand, $\chi \propto \varrho \iota \tau \eta \dot{\varrho} \varrho \iota$ appeared from Xenophon onwards. The late appearance of the word in Greek dedicatory inscriptions was observed by HEwITT (1912), BEER (1914), p. $118-31$.

${ }^{66}$ E.g. Paus., I, 42.5, IC, I iii, 1 (= MCCABE, Teos Inscriptions, no. 4), xvi, 3, III iii, 9-10; RE s.v. Apollo, 47; PARKER (1983), p. 341.

${ }^{67}$ Callim., Hymn IV, 278.

68 The word is used in e.g. Kafizin, nos. 76, 100, 103, 106, 117b, 135a, 138b, 144c, 151, 153, 154, 169b, 171, 181, 192, 193, 196, 198, 201, 204, 216, 217a, 220a, 237, 238, 256b, 275, 286, 299.

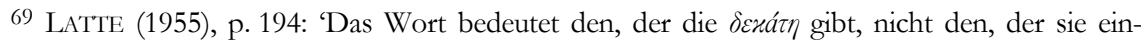
nimmt. Es liegt also am nächsten, zu verstehen, dass er den Nymphen den Zehnten von seiner Arbeit oder seinem Gewinn gelobt hatte und nun darbringt'; BINGEN (1982), p. 171, sees in it no relation with tax-farming: 'la $\delta \varepsilon x \alpha \dot{\tau} \tau \eta$ n'est certainement pas une dîme sacrée en nature sur un ensemble d'activités économiques... La notion de 'dîme' a pu être ici plus symbolique que quantitative', MASSON (19832 [1961]), p. 256: 'un potier qui consacrerait le dixième'. But later in MASSON 


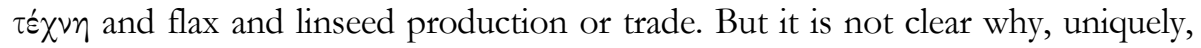
Onesagoras needed to assume the title 'tithe-bringing' to refer to the commonplace act of bringing a tithe.

Another explanation, that suggested by Pouilloux, is to see Onesagoras as an intermediary between the Nymph and those who paid a tithe. Pouilloux suggested that 'la divinité percevait une dîme sur les récoltes par l'intermédiaire d'un personnage', and that 'il est chargé de prélever une dîme et il en fait offrande à la divinité'. ${ }^{70}$ Given that flax and linseed constituted an important source of income, this would most likely concern a tithe from agricultural produce payable by the koinonia (or koinonial) to the Nymph, or possibly from the profits of the association(s) more generally. On this theory, Onesagoras would cease to be a religious enthusiast who brought some 270 separate dedications on his own account: he was acting as an agent for others, and we would be dealing with equally remarkable group piety. But even so, he might have been chosen by the group(s) for the service of the Nymph because he had a special connection to the goddess. Yet the problem shifts to the koinonia on whose behalf ex hypothesi Onesagoras was acting: recurrent 'tithes' (whether vowed voluntarily, or compulsory in some way) brought by a religious society are without parallel. Moreover, it is not clear why Onesagoras should inscribe the dedications with his own name rather than that of the koinonia (or koinoniai).

A third possibility which has been raised is that the dekatai signified in the words dekatephoros and dekatismos concern not religious tithes to the Nymph, but 'secular' tithes or taxes payable to Onesagoras and/or the association(s) from a third party (other than the koinonia/al). In other words, both dekatephoros and dekatismos refer to the collection of taxes of some sort. This leads some scholars to assume that Onesagoras and/or the association(s) was a tax-farmer and/or a tax-farming association(s) engaged in the collection of taxes. Thus Mitford took Onesagoras to be the 'managing director' of 'the company of Zenon', which was engaged in the collection of tithes on flax and linseed. ${ }^{71}$ And yet why should a tax-farmer or a tax-farming corporation offer these vessels to the Nymph?

It seems to me more likely that we are dealing with a religious rather than a commercial phenomenon, and that the dekatai were dedications rather than nonreligious payments. Onesagoras was most probably a dedicator or a tithe-bringer in the service of the Nymph. This can be supported by numerous parallels. It was a customary practice in ancient Greece to bring tithes to the gods using the proceeds from a diversity of human activities, such as farming, fishing, handicraft work, and trade. Such tithes are most abundant in Athens and Cyrene, but are

(1981), p. 630, he rejects his earlier view, suggesting instead that 'il signifie évidemment « receveur de la dime $»$.

${ }^{70}$ Pouilloux (1982), p. 100.

71 Mitford (1950), p. 102: 'a receiver of tithes'; MitFord (1980), p. 256; followed by KARAGEORGHIS (2005), p. 251: 'a tax-collector'. 
also widely attested in other parts of Greece. A wide variety of dedications have come down to us, ranging from humble ceramic vessels to expensive marble monuments. ${ }^{72}$ Equally plausible is the suggestion that Onesagoras was a religious intermediary bringing tithes for others to the Nymph. The word dekatephoros possibly indicates some sort of a religious title. In Athens in the Classical period there were basket-bearers called kanephoroi, who walked at the front of sacrificial processions carrying on their heads a basket containing the essential items for sacrifice. We also have evidence of metics serving as parasol-bearers (skiadephoroi), tray-bearers (skaphephoroi) and stool-bearers (diphrophoroi) in the Panathenaic procession. ${ }^{73}$ By comparison with these known titles, it is attractive to think that dekatephoros was a religious title referring to the duty of carrying tithes to the goddess. Considering that flax and linseed feature prominently in the Kafizin dossier, I wonder whether Onesagoras might have been responsible for collecting tithes on the agricultural produce payable by the association(s) to the Nymph.

Whether Onesagoras was bringing items of pottery on behalf of himself or others, these numerous dedications and the act of dedicating them must have been for Onesagoras a way of maintaining a close relation with the Nymph. His exceptional devotion and special relation with the Nymph are strikingly similar to those exhibited by Archedemos at Vari, Pantalkes at Pharsalos, and Artemidoros at Thera mentioned at the beginning, all of whom fashioned a local sanctuary of the Nymphs (and/or other divinities), adorned it with dedications and inscriptions and, in the case of Archedemos and Artemidoros, self-portraits, thus providing us with valuable historical examples of nympholepts. ${ }^{74}$ Amid the different manifestations of nympholepsy, such as a heightened state of eloquence and understanding, the ability to prophesy, physical seizure by the Nymphs, and a strong commitment to the establishment or maintenance of a cult, it is in the last respect that Onesagoras resembles a nympholept: he displays a remarkable degree of religious devotion and possibly service to the Nymph. The dedications inscribed with his name were more frequent and numerous than those attested for any other individual made to any divinity in antiquity; and what has come down to us must have been only a fraction of what was actually dedicated. The remarkable

72 Athens: e.g. IG $\mathrm{I}^{3} 533,536,540,542,544,548 \mathrm{bis}, 565,567,574,583 \mathrm{p}, 608,616-7,621$, 631, 638, 644, 652, 655f, 657, 660, 667, 691, 698, 704, 727, 735, 738, 764, 766-7, 775, 779, 794, 800, 809, 810, IG II ${ }^{2}$ 4318, 4587, 4853, 4889, 4909. Cyrene: e.g. SEG 9, 76; 9, 78; 9, 80; 9, 84; 9, 87-88; 9, 100; 9, 303-4; 9, 307; 9, 309-12; ASAA n.s. 23-4 (1961-2), p. 219-375, nos. 35-41, 49, 132-5, 137-42, 151-2, 248-52; SEG 38, 1870, SEG 44, 1541, nos. 6, 7, 8. Most of these tithes in Cyrene are collected in Parker (1983), 341. On tithing practices, see also Rouse (1902), p. 39-94, LANSDELL (1906).

73 See e.g. Ar., Av., 1549-1552, Din., fr. 16.5 ap. Harp., $\sigma$ 21, Ael., VH, 6.1, Poll., III, 55; WhiteHeAd (1977), p. 87-88, PARKer (2005), p. 170, n. 56, p. 223-226, 258.

${ }^{74}$ On these three nympholepts, see n. 11-14 above. On the literary motif of nympholeptic encounters, see PACHE (2011), passim. However, PACHE (2011) understands nympholepsy narrowly in terms of a mortal man's love relation with, and physical seizure by, a goddess, when in fact one could be a nympholept without experiencing an erotic encounter with a goddess. 
amount of dedications bear out the phrase that Onesagoras (dedicated) ' $\varepsilon \mu \varepsilon \varkappa \alpha i$ $\alpha^{\prime} \lambda \lambda \alpha \pi \circ \lambda \lambda \alpha^{\prime}$ frequently applied in the dedicatory inscriptions. While Onesagoras' motivations and the circumstances of dedication may escape us, his special relation - whether as a dedicator himself or an intermediary between the Nymph and others - with the goddess strikes the reader throughout the corpus. One notices a sense of pride in his inscriptions, with repeated mention of his name and his role as dekatephoros, sometimes accompanied by what might have been his self-portraits. Although Onesagoras never described himself explicitly as nympholeptos, the exceptional quantity of the dedications, the intensity of his devotion, his close bonds with the Nymph, and the language with which he described his relation with the goddess makes this interpretation very likely.

Although much remains uncertain about Onesagoras and the koinonia (or koinoniai) associated with him, the finds at Kafizin provide important testimonies to the devotion of an ordinary individual (or possibly a group or groups), presenting us with valuable material for the study of personal (or group) piety and an individual's close relation with his favoured goddess in a way not normally possible for most ordinary ancient worshippers. Despite the many uncertainties and questions raised earlier about the corpus, what is certain is that an irreducible quantity of religious activities is involved here. Onesagoras adds to our knowledge of dedicatory practices by showing that individuals (or groups) could bring gifts to the gods more frequently than is sometimes thought possible. He provides a rare example in the study of Greek religion where, outside communal festivals, and possibly outside any specific need to seek divine favours, an individual (or a group) could express his/its piety and reinforce his/its ties with the divinities by repeatedly bringing something to the gods. The humble and simple nature of the ceramic vessels also shifts our attention away from the expensive monumental dedications which have traditionally dominated the attention of historians. This valuable dossier deserves more attention in the study of religious practices than it has hitherto received.

St. Antony's College,

Theodora Suk Fong JIM

Oxford, OX2 6JF

Email:suk.jim@classics.ox.ac.uk 


\section{Bibliography}

P. Amandry, 'Le culte des Nymphes et de Pan à l'antre Corycien', Études delphiques, Paris/Athens, 1984 (BCH, suppl. 9), p. 395-425.

H. BEER, Aparche und verwandte Ausdrücke in griechischen Weibinschriften, diss., Würzburg, 1914.

A. Bernand, O. MAsson, 'Les inscriptions grecques d'Abou-Simbel', REG 70 (1957), p. 1-46.

J. Bingen, 'Terence B. Mitford, The Nymphaeum of Kafizin. The Inscribed Pottery', CE 57 (1982), p. 170-173.

P. Bonnechere, 'Prairies et jardins grecs de la Grèce de Platon à l'Angleterre d'Alexander Pope', in Delruelle and Pirenne-Delforge (eds.), 2001, p. 29-50.

—, Trophonios de Lébadée, Leiden, 2003.

Ph. Borgeaud, Recherches sur le dieu Pan, Geneva, 1979.

W.R. ConNOR, 'Seized by the Nymphs: Nympholepsy and Symbolic Expression in Classical Greece', ClAnt 7 (1988), p. 155-189.

É. Delruelde, V. Pirenne-Delforge (eds.), Kêpoi. De la religion à la philosophie. Mélanges offerts à André Motte, Liège, 2001 (Kernos, suppl. 11).

E.H. Dohan, R.G. Kent, 'New Inscriptions from Cyprus’, AJA 30 (1926), p. 249-258.

E. Ekman, 'Appendix III', in E. Gjerstadt, J. Lindros, E. Sjöquist, A. Westholm, The Swedish Cyprus Expedition, Finds and Results of the Excavations in Cyprus, 1927-1931, vol. 3, Stockholm, 1937, p. 621-632.

Fr. GRAF, 'Bemerkungen zur bürgerlichen Religiosität im Zeitalter des Helenismus', in M. WÖRRLE, P. ZANKer (eds.), Stadtbild und Bürgerbild im Hellenismus, München, 1995, p. 103-114.

K. Hadjioannou, 'Kafizin and the Cypriote Dialect. A Review Article', RDAC 1982, p. 254259.

M. Halm-Tisserant, G. SieberT, 'Numphai', LIMC VIII (1997), p. 891-902,

M.H. HANsen, T.H. Nielsen (eds.), An Inventory of Archaic and Classical Poleis, Oxford, 2004.

A. Henrichs, 'Despoina Kybele: ein Beitrag zur religiösen Namenkunde', HSCP 80 (1976), p. 253-86.

A. Hermary, 'Un nouveau vase inscrit de Kafizin', CCEC 36 (2006), p. 63-72.

R. Herzog, Koische Forschungen und Funde, Hildesheim, New York, 1983 [1899].

J.W. HewitT, 'On the Development of the Thank-Offering among the Greeks', TAPhA 43 (1912), p. 95-111.

G.F. HiLl, A History of Cyprus, Cambridge, 1940, vol. 1.

N. Himmelmann-Wildschütz, Theoleptos, Marburd, 1957.

V. KARAgeorghis, Greek Gods and Heroes in Ancient Cyprus, Athens, 1998.

-, H. Matthäus, S. Rogge (eds.), Cyprus: Religion and Society from the Late Bronze Age to the end of the Archaic Period, Möhnesee-Wamel, 2005.

H. LansDell, The Sacred Tenth. Studies in Tithe-giving, Ancient and Modern, London, 1906, vols. 1-2.

J. Larson, 'The Corycian Nymphs and the Bee Maidens of the Homeric Hymn to Hermes', GRBS 36 (1995), p. 341-357.

—, Greek Nymphs: Myth, Cult, Lore, Oxford, 2001.

K. LATTE, 'Zur griechischen Wortforschung II', Glotta 34 (1955), p. 190-202.

D.F. MCCABE, Teos Inscriptions. Texts and Lists, Princeton, 1985.

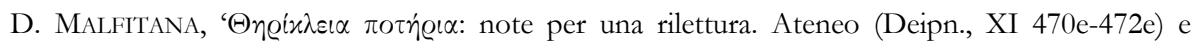
alcuni kantharoi da un santuario Cipriota', NAC 33 (2004), p. 217-247.

O. MAsson, ‘À propos des inscriptions chypriotes de Kafizin’, BCH 105 (1981), p. 623-649.

—, Les inscriptions chypriotes syllabiques, Paris, $1983^{2}$ [1961]. 
I. Michaelidou-Nikolaou, 'Nouveaux documents pour le syllabaire chypriote', BCH 117 (1993), p. 343-347.

T.B. MitForD, 'Kafizin and the Cypriot Syllabary', CQ 44 (1950), p. 97-106.

—, 'Three Documents from Classical Cyprus', in E. Grumach (ed.), Minoica. Festschrift zum 80. Geburtstag von Johannes Sunwall, Berlin, 1958, p. 260-275.

—, The Nymphaeum of Kafirin, Berlin, New York, 1980.

J.L. MYres, Handbook of the Cesnola Collection of Antiquity from Cyprus, New York, 1914.

C.O. PACHE, A Moment's Ornament. The Poetics of Nympholepsy in Ancient Greece, New York, Oxford, 2011.

O. PAlagia, 'Cult and Allegory: the Life Story of Artemidoros', in J.M. SANDERS (ed.), Philolakon. Lakonian Studies in Honour of Hector Catling, Athens, 1992, p. 171-177.

R. PArker, Miasma, Oxford, 1983.

-, Athenian Religion. A History, Oxford, 1996.

-, Polytheism and Society at Athens, Oxford, 2005.

A. PASQUIER, 'Pan et les Nymphes à l'antre corycien', Études delphiques, Paris/Athens, 1977 (BCH, suppl. 4), p. 365-387.

D. PILIDES, 'Potters, weavers and sanctuary dedications: possible evidence from the hill of Agios Georgios in the quest for territorial boundaries', CCEC 34 (2004), p. 155-172.

J. Poullloux, 'Le dernier livre de T. B. Mitford', RPh 108 (1982), p. 99-103.

C. PrÊtre et al. (eds.), Le donateur, l'offrande et la déesse, Liège, 2009 (Kernos, suppl. 23).

J. ROBERT, L. ROBERT, 'Bulletin épigraphique', REG 94 (1981), p. 362-485.

L. ROBERT, 'Sur un Apollon oraculaire à Chypre', CRAI 1978, p. 338-344.

W.H.D. Rouse, 'Tithes, First-fruits, and Kindred Offerings', in Greek Votive Offerings, Cambridge, 1902, p. 39-94.

C. Sourvinou-Inwood, Hylas, the Nymphs, Dionysos and Others, Stockholm, 2005.

R. Stores, B. J. Brien, The Handbook of Cyprus. The 9th issue, London, 1930.

F.T. VAn StRaten, 'Daikrates' Dream. A Votive Relief from Kos, and some other kat'onar Dedications', BABesch 51 (1976), p. 1-38.

—, 'Gifts for the Gods', in H.S. Versnel (ed.), Faith, Hope and Worship, Leiden, 1981, p. 65-105.

H.S. VerSNEL, Coping with the Gods, Leiden, 2010.

C.H. WeLLER, 'The Cave at Vari', AJA 7 (1903), p. 263-288.

D. WhiteHeAD, The Ideology of the Athenian Metic, Cambridge, 1977. 